\title{
FOREST WAQF STRATEGY IN PROTECTING INDIGENOUS FORESTS IN ACEH PROVINCE
}

\author{
Lukman Hamdani*1, Bayu Taufiq Pasummah² \\ ${ }^{1}$ Lecturer at university of Yarsi and Researcher at the Indonesia Waqf Institute, Email: \\ pangeranhaluna@gmail.com \\ ${ }^{2}$ Director of Indonesia Waqf Institute and Senior lecturer at Universiti Malaysia Terengganu, \\ Email: btaufiq@gmail.com \\ *Corresponding author: pangeranhaluna@gmail.com
}

(Received: 15 $5^{\text {th }}$ September 2021; Accepted: $28^{\text {th }}$ November 2021; Published: $31^{\text {st }}$ December 2021)

Keywords:

Forest; Waqf,

Environment;Aceh

Province; Protecting;

Indigenous;

\begin{abstract}
A B S T RA C T
Aceh's forest is a biosphere reserve, a world heritage, and a natural habitat for animals, such as the Sumatran tiger, Ceumpala Kuneng, and Sumatran elephant. However, Aceh's forests are currently experiencing a deficit related to uncontrolled land conversion, among others due to forest conversion to oil palm land, gold mining, illegal logging, and illegal new stone mining. Although Aceh's forest area as of 2019 was 2,989,212 hectares, the damage figure reached 15,140 hectares. Thus, this study aims to create a model of Aceh's forest waqf to protect it from the natural damage caused by humans. This qualitative research utilized the ANP (Analytic Network Process) analysis tool. The study results revealed that the most important factors for Aceh's forest waqf model were components of forest waqf, companies, and the government. Forest waqf solutions include infaq and shadaqah fund solutions, waqf institutions, and full-time nazhir (waqf manager). The company's solutions encompass institutional audits, citizen patrols, and reporting. Meanwhile, the government's solution can be in the form of
\end{abstract}


a limitation solution, policy evaluation, and local government involvement. Besides, the strategy of forest waqf in protecting indigenous forests in Aceh Province can be in the form of synergies between forest waqf and BAZNAS (National Zakat Amil Agency), monitoring local officials, and granting authority to local governments.

\section{INTRODUCTION}

Forests are vital in life since forests produce natural oxygen for the survival of life. There are also diverse faunal life arrangements that can make the human eye aware of God's creation. However, nowadays, forests are starting to erode, in the sense that many not-responsible parties convert natural forests into oil palm fields, illegal logging, hunting for animals, and burning forests. According to Walhi data, Aceh's forest area was 3,004,352 hectares in 2018 and 2,989,212 hectares in 2019. In addition, Aceh's forest cover lost in 2018 was 15,140 hectares and 15,071 hectares in 2019. Since 2020, there have been 135 ecological disasters, and from January to August 2021, there have been 421 times.

In this regard, forest waqf, especially in the Jantho area, are one of the keys to answering these problems because, so far, the ecological impacts that have occurred are visible to the Aceh people. In fact, according to research data, Aceh's forest is one of the biosphere reserves and one of the world's heritage (Ali, 2021).

At least, there are some recommendations for this forest to recover quickly. First, it is necessary to review the contracts of land clearing agreements whether they bring more problems or not. Second, there must be a clear mapping between the Ministry of Environment and Forestry and BAPPENAS regarding which forest areas should not be used for industrial activities. Third, the forest waqf needs to be cooperated to restore critical areas. Fourth, the Juntho forest waqf can be used as an instrument to determine the exclusive zone area to maintain nature conservation (Cochard, 2017).

Therefore, the method in this research was descriptive qualitative, employing primary and secondary data. Primary data were in the form of interviews via zoom with the founders of forest waqf and distributing questionnaires to experts and practitioners. Meanwhile, secondary data were sourced from websites related to forests in Aceh and their problems and from journals and books related to Aceh's forests and waqf. The analysis tool utilized was ANP (Analytic Network Process), a qualitative method in making decisions by mapping the most important aspects and problems as well as their solutions and strategies related to Aceh's forest waqf through Super Decision Software. In this study, seven experts/practitioners in the field of forest and waqf were involved. In this 
study, the researchers also discussed several things, including the basis for forest waqf and the integration of Aceh's forest waqf in protecting the environment (Islam, 2012). In addition, the results of this study regarding Aceh's forest waqf are in the form of aspects and problems as well as solutions and strategies.

\section{FOREST WAQF}

At the time of the Prophet SAW, there was already a concept of waqf that could be qiyas with the concept of forest waqf, namely in the form of garden waqf by Umar bin Khattab and well waqf by Uthman bin Affan. Qiyas in question is the concept of providing benefits to the people through the waqf assets. The history of forest waqf has also existed since the Ottoman Empire in Turkey, where at that time, there were four types of forest ownership with details: (1) State-owned forests with an area of up to 10 million hectares; (2) Forest waqf with an area of up to 100,000 hectares; (3) Urban forest with an area of 146,000 hectares; (4) Privateowned forest with an area of 539,000 hectares. The basis of the hadith in the forest waqf is, "there is no Muslim who plants a tree or a plant, and then birds or humans or other animals eat it unless he gets alms for it." "When the Day of Judgment is established, but there is a date palm seed in the hand of one of you, if he can stand until he plants it, then do it." This hadith accommodates the importance of planting trees for the environment and protecting nature and is a strengthening hadith for forest waqf (Baird, 2008).

The concept of waqf for the environment is not yet popular in Indonesia, but it has been implemented in Kuwait through the Kuwait Awqaf Public Foundation (KAPF) with the Environmental Fund program since 1995 (Rohaini, 2020). KAPF is not only tasked with collecting waqf funds but also managing and distributing its benefits for environmental purposes. KAPF also established the Regional Organization for the Environmental Protection of the Gulf, reforested mosques and school gardens, tree planting projects, and funded various environmental organizations. In addition, KAPF cooperates with companies in Kuwait, one of which is in the form of investing (shares). With the role of KAPF in the company, KAPF also encourages the company's policies and activities to be environmentally friendly (Islam, 2012).

Furthermore, the forest waqf program is one form of implementing the waqf concept, which can be an instrument in supporting environmental conservation. Forest waqf is an innovation in the field of waqf empowerment. Forest waqf can play a role in maintaining microclimate stability, preserving biodiversity, conserving water, and preventing natural disasters (Islam, 2020). As the use of assets in this program is to preserve life and ecology, by regulation, forest waqf is included in the category of waqf for other public welfare, which does not conflict with sharia and laws and regulations, as regulated in Article 22 of Law Number 41 of 2004 about waqf. In addition, Article 16 also explains that immovable objects include plants and other objects related to land. In other words, the forest 
waqf program comprises the forest and the plants on it. Currently, three forest waqfs have been initiated by the community in Indonesia. The first is the forest waqf in Jantho, Aceh Province, which young nature lovers built in 2012 (Zulfan, 2018). Then, the Leuweung Sabilulungan forest waqf was developed by the Bandung Regency Government in 2013. The last is the forest waqf in Cibunian Village, Pamijahan Sub-district, Bogor Regency, which the Yassiru Foundation developed in 2018 (Yeoh, 1994).

Specifically, the concept of waqf for the environment in Indonesia can be found in Aceh Province, which began with the purchase of critical and potential lands to be productive and preserve the environment in 2012. Meanwhile, the concept of waqf in a forest waqf started with the initiation of fundraising by the forest waqf community by raising donations, which were sent through a bank account in the name of one of the waqf initiators. Once collected, the funds were disbursed in stages, and the land was purchased to create forest waqf, namely in Gampong Jantho and Gampong Data Cut in Aceh Besar Regency. These lands were then converted into forests, which are expected to provide ecological and economic benefits, for example, by turning them into nature schools. Furthermore, the management of forest waqf was left to the local village, which was carried out by village institutions or commonly called gampongs, to be utilized in accordance with their objectives, namely ecological and economic goals. Based on this, it can be concluded that the waqf implemented here is basically a land waqf. However, its designation is to be used as a forest for environmental sustainability to realize general welfare, as is the function, purpose, and designation of waqf property.

\section{INTEGRATION OF ACEH FOREST WAQF IN PROTECTING THE ENVIRONMENT}

According to data from the Ministry of Environment and Forestry (KLHK), the number of forests that have changed functions or deforestation in Indonesia was 115.5 thousand hectares in the 2019-2020 period (Yaakob, 2017). In the previous period, in 2018-2019, deforestation reached 462.5 thousand hectares. Meanwhile, in 2017-2018, it was 439.4 thousand hectares. For the 2016-2017 period, it was 480 thousand hectares, and the highest period with 629.2 thousand hectares was in 20152016. In total, from 2015 to 2020, the deforestation rate in Indonesia reached 2.1 million hectares although, in the 2019-2020 period, it has decreased to 75 percent.

According to Walhi data, Aceh's forest area was 3,004,352 hectares in 2018 and 2,989,212 hectares in 2019, while Aceh's forest cover lost was 15,140 hectares in 2018 and 15,071 hectares in 2019. In addition, since 2020, there have been 135 ecological disasters, while from January to August in 2021, there have been 421 times. The beginning of Aceh's forest waqf was with crowdfunding of 15 million from public funds, and the first land purchase was a hectare on critical land in Data Cut Village, Jantho Sub-District, Aceh Besar Regency (Suwardi, 2020). The types of trees planted in forest waqf are ficus/fig trees for water infiltration. Birds 
and primates favor the fruit. It is beneficial for animals since the fruit can be eaten by animals and as nesting places. In addition, 1000 seedlings of durian, jackfruit and sentang were planted.

Currently, the Jantho forest waqf area is 5 hectares; more precisely, as of September 2020, it was 47,420 $\mathrm{m}^{2}$. It consists of $9000 \mathrm{~m}^{2}$ in Gampong Data Cut, Kota Jantho Sub-district, Aceh Regency and 38,420 $\mathrm{m}^{2}$ in Gampong Jantho, Kota Jantho Sub-district, Aceh Besar Regency, with a total donation as of May 4, 2021, amounting to 146,987,117.26. Meanwhile, activities that can support the sustainability of forest waqf include the purchase of T-shirts, rowing, and planting activities.

Aceh forest waqf in the form of aspects and problems as well as solutions and strategies

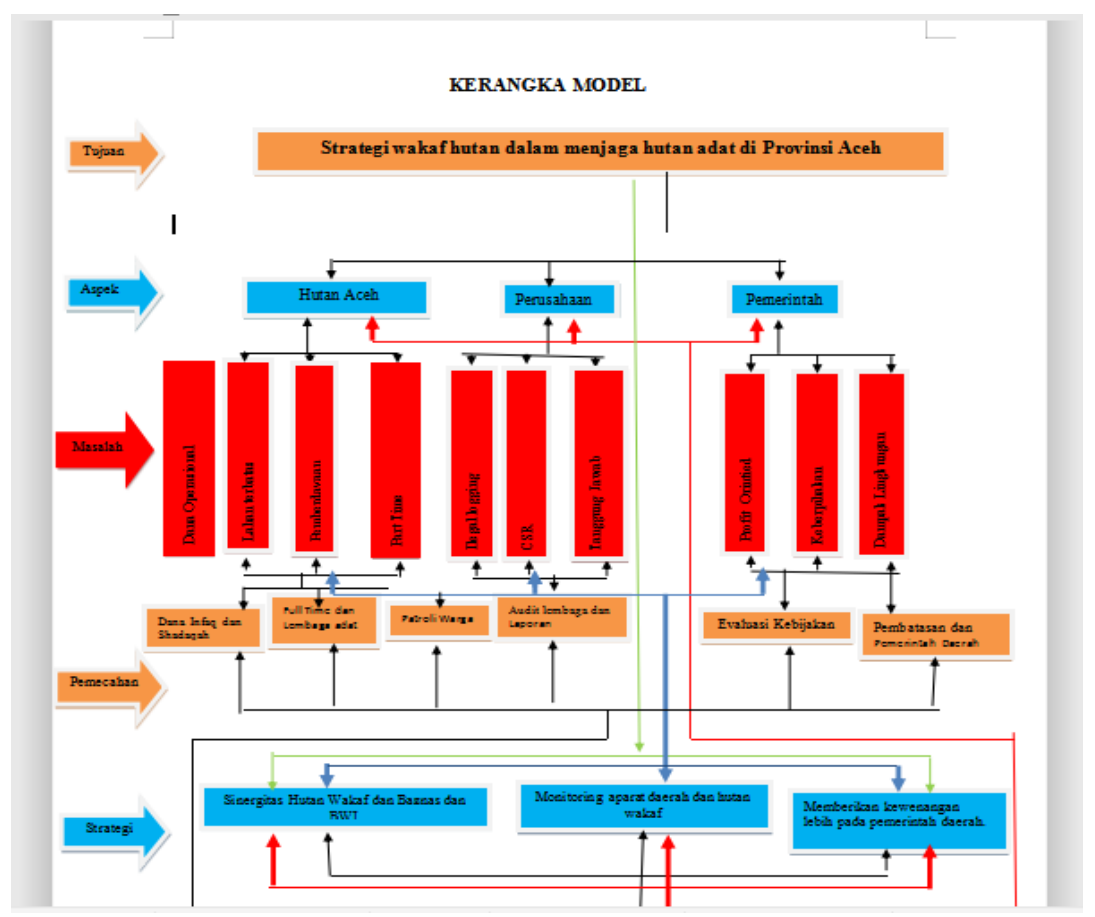

MODEL FRAMEWORK: INTERVIEW RESULTS

Model Framework

Objective: Strategy of forest waqf in protecting indigenous forests in Aceh Province

Aspect: Aceh Forest, Company, Government

Problems:

-Operational funds, limited land, empowerment, part-time nadhir

-Illegal logging, CSR, responsibility

-Profit oriented, partiality, environmental impact 
Solution: Infaq and sadaqah funds, full-time nadhir, citizen patrols, institutional audits and reporting, policy evaluation, restrictions and local government

Strategy: Synergy of forest waqf and BAZNAS and BWI (Indonesian Waqf Board), monitoring of regional apparatus and forest waqf, and giving more authority to local government

The figure above results from the forest waqf model from the forest waqf strategy in protecting indigenous forests in Aceh Province. Those are the results of interviews with experts and practitioners in the field of forest and waqf. Aspects obtained include components of forest waqf, government, and companies. In addition, there are solutions from the three, and there are also strategies needed to strengthen forest waqf in Aceh Province (Karam, 2019).

\section{ASPECTS OF SYNTHESIS RESULTS ANALYSIS}

In this discussion, the synthesis results on the aspect cluster are described to determine the forest waqf strategy in protecting indigenous forests in Aceh Province (Mangunjaya, 2019). Based on the data processing results through Super Decision Software, the priority of the problem according to the opinion of all respondents was obtained, as shown in the following figure:

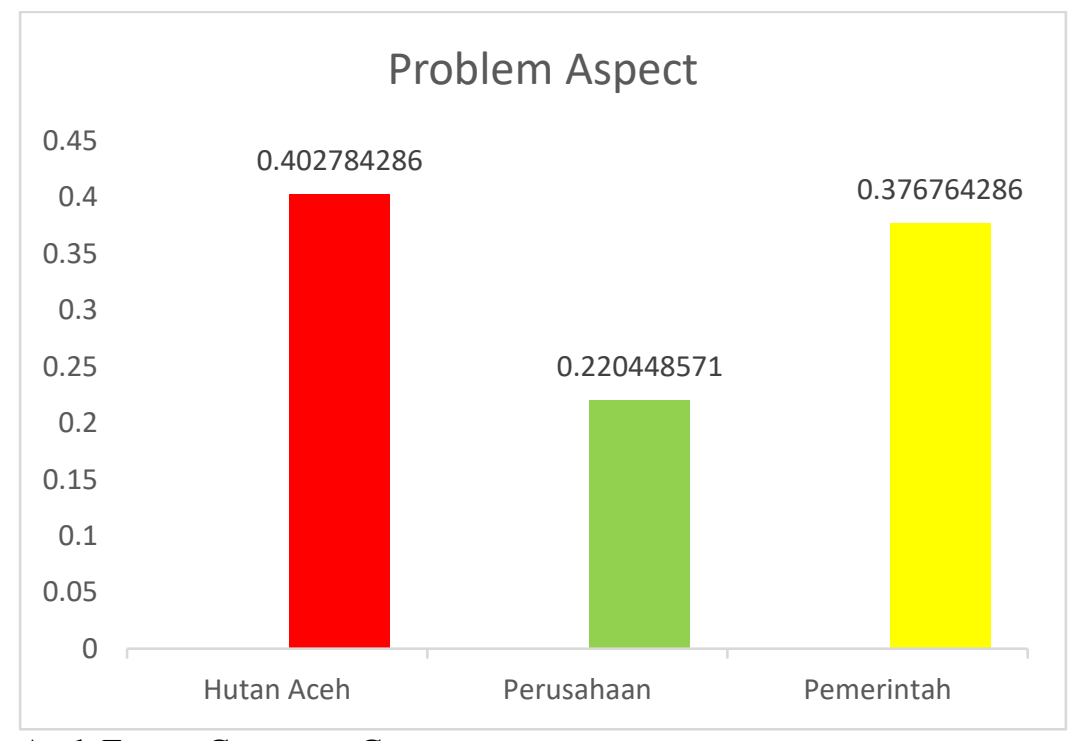

Aceh Forest, Company, Government

Figure 1.1 Priority Synthesis Results on Problem Aspects Based on Mean Score

Figure 1.1 above displays that based on the combined opinion of the respondents, the most priority problem in determining the forest waqf strategy in protecting indigenous forests in Aceh Province was the 
problem of Aceh's forests itself at $40.3 \%$, followed by the government at $37.6 \%$, and the company problems by $22 \%$ in the last rank. The result of obtaining the rater agreement value of all respondents was $34 \%$. It signifies that the respondents' agreement level on the priority order of the problem aspects, in the form of Aceh's forests, the community, and the government, was $34 \%$.

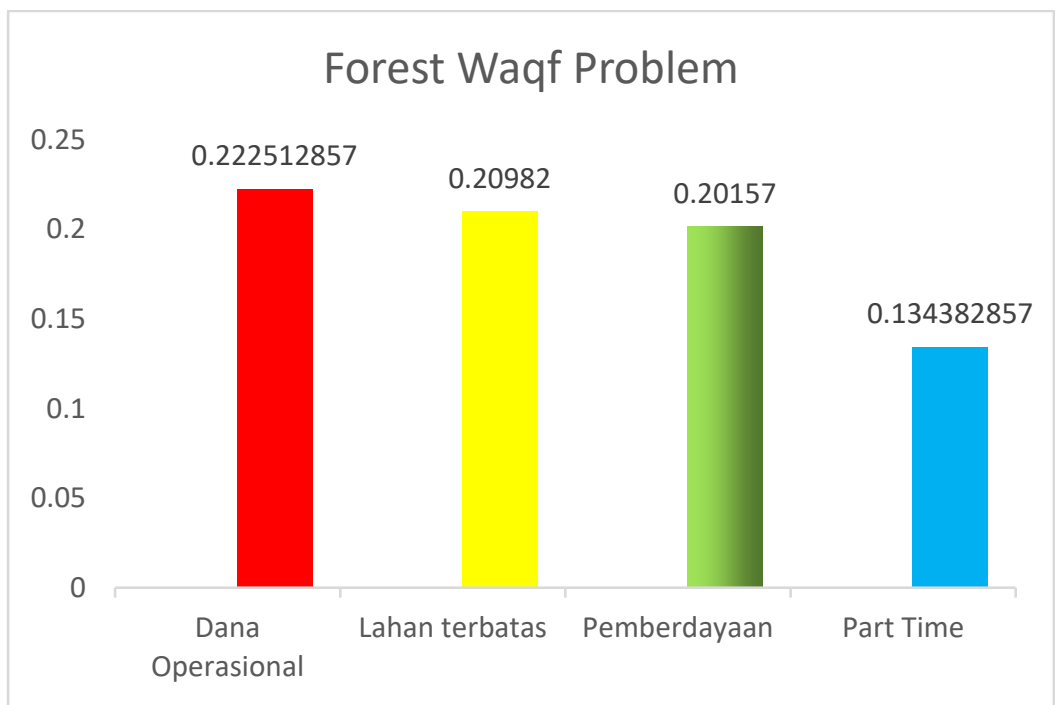

Operational funds, limited land, empowerment, part-time nadhir

\section{Figure 1.2 Priority Synthesis Results of Forest Waqf Problems Based} on Mean Score

The figure above shows that based on the combined opinion of the respondents, BAZNAS's most priority problem in determining the forest waqf strategy in protecting indigenous forests in Aceh Province was the issue of operational funds by $22.2 \%$, followed by the problem of limited land at $20.9 \%$, the problem of empowerment by $20 \%$, and then by parttime nadhir problems by $13 \%$. The result of obtaining the rater agreement value of all respondents was $14 \%$, meaning that the respondents' agreement level on the priority order of Aceh's forest waqf issues was $14 \%$. 


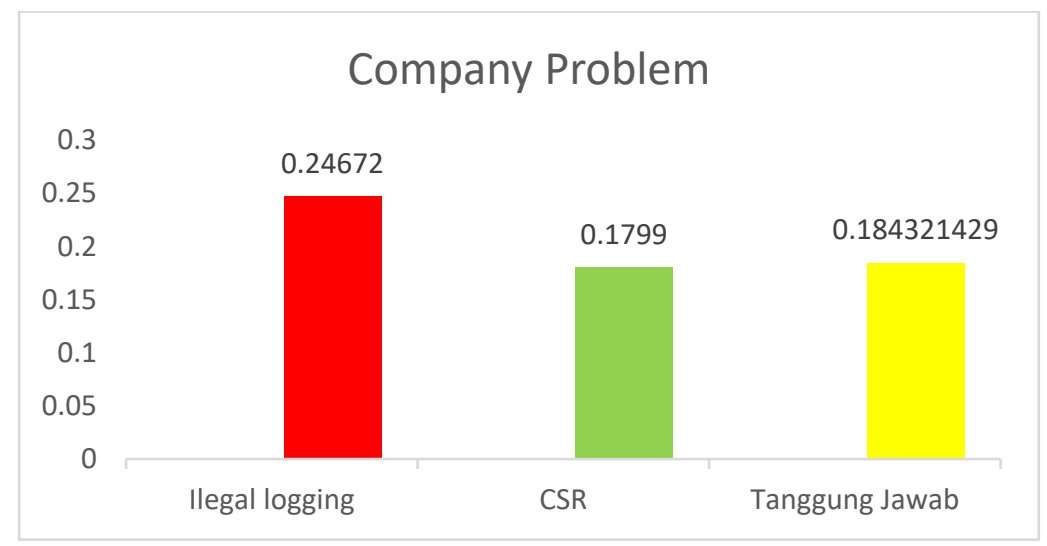

Illegal logging, CSR, responsibility

Figure 1.3 Priority Synthesis Results of Company Problems Based on Mean Values

Figure 1.3 above reveals that based on the combined opinion of the respondents, the most priority community problem in determining the forest waqf strategy in protecting indigenous forests in Aceh Province was the problem of illegal logging at $24.6 \%$, followed by the problem of responsibility at a figure of $18.4 \%$ and CSR issues at $17.9 \%$. The result of obtaining the rater agreement value of all respondents was quite low at $20 \%$. It indicates that the respondents' agreement level on the priority order of Illegal logging, responsibility, and CSR issues was not a priority, which was $20 \%$.

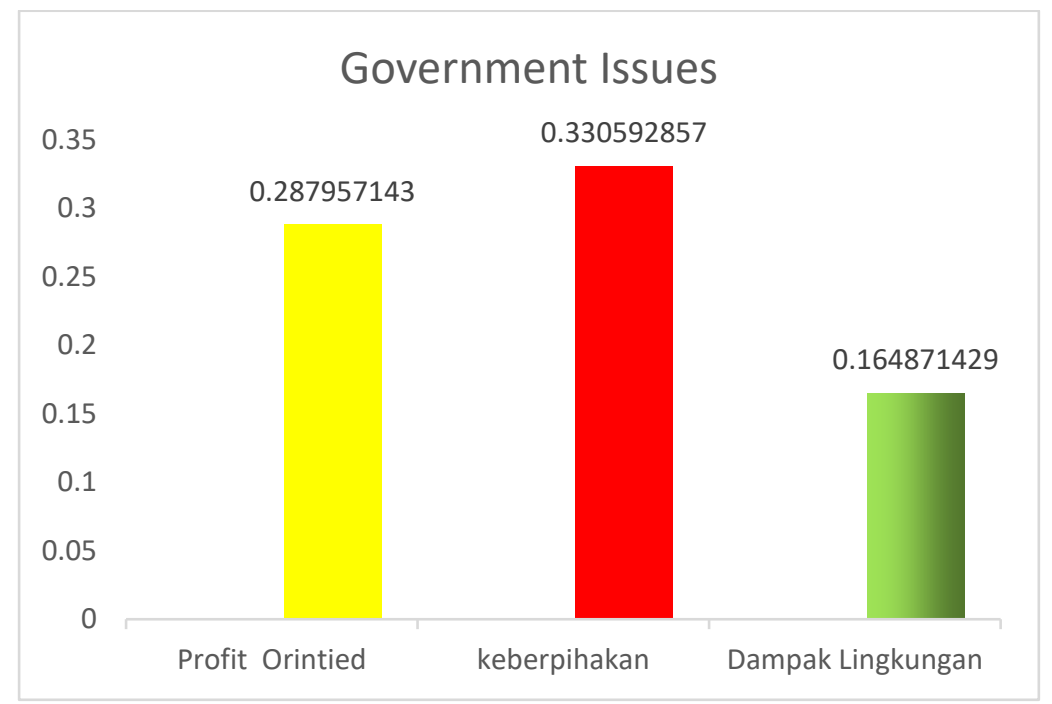

Profit oriented, partiality, environmental impact

Figure 1.5 Priority Synthesis Results of Government Problems Based on Mean Score 
From Figure 1.5 above, based on the combined opinion of the respondents, the government's most priority issue in determining the forest waqf strategy in protecting indigenous forests in Aceh Province was partiality at $33 \%$, followed by profit-oriented issues at $28 \%$ and environmental impacts at $16 \%$, which ranked third. The result of obtaining the rater agreement value of all respondents was $11 \%$. It means that the respondents' agreement level on the priority order of government issues was in the form of partisanship, profit-oriented, and environmental impact since the rater agreement value reached $11 \%$.

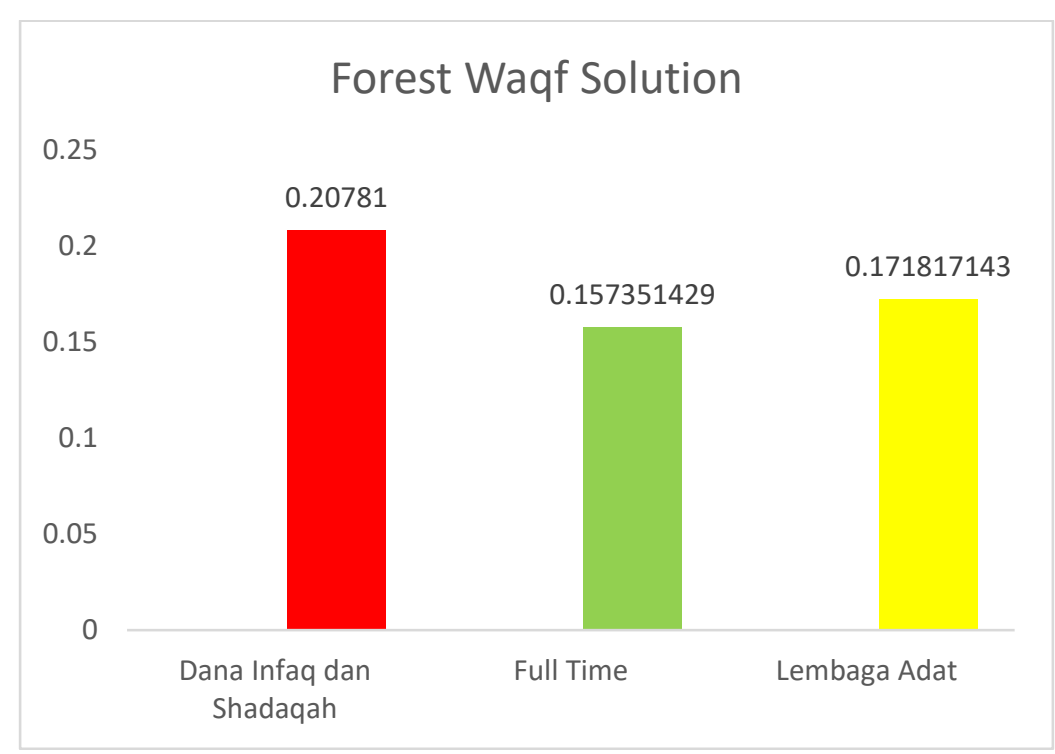

Infaq and sadaqah funds, full-time nadhir, customary institution

Figure 1.6 Priority Synthesis Results of Solutions for Forest Waqf Based on Mean Value

Figure 1.6 above presents that based on the combined opinion of the respondents, the most priority solution in determining the forest waqf strategy in protecting indigenous forests in Aceh Province was a solution focusing on the real sector by $20 \%$, ranked first, the solution for customary institutions by $17 \%$, ranked second, and full-time nadhiz by $15 \%$, ranked last. The result of obtaining the rater agreement value of all respondents was $10 \%$, denoting that the respondents' agreement level was small concerning the order of priority solutions, in the form of infaq and shadaqah fund solutions, waqf institutions, and full-time nadhir, which was $10 \%$. 


\section{Company Solutions}

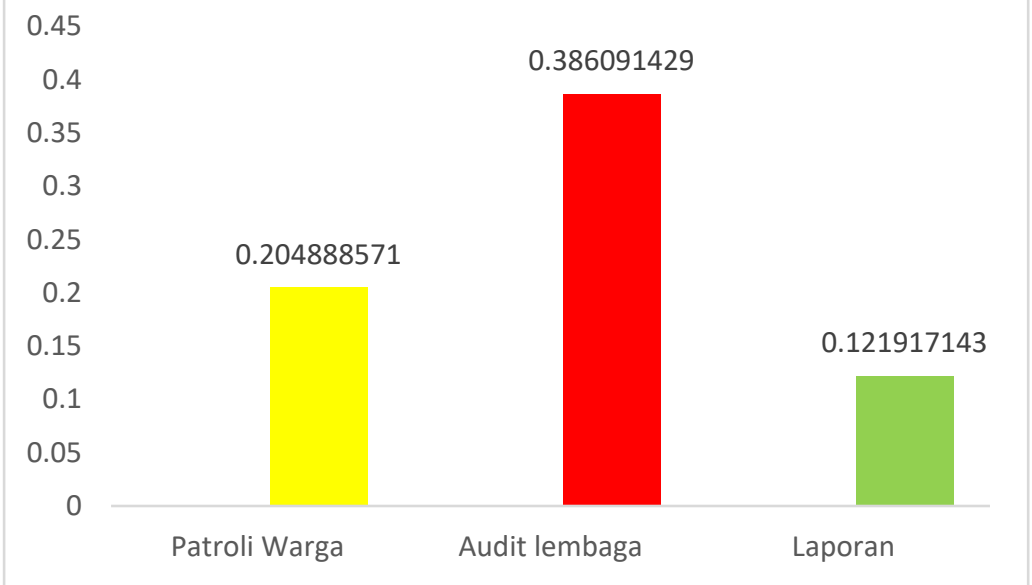

Citizen patrols, institutional audits, and reporting

Figure 1.7 Priority Synthesis Results of Company Solutions Based on Mean Score

Figure 1.7 above shows that based on the combined opinion of the respondents, the most priority solution in determining the forest waqf strategy in protecting indigenous forests in Aceh Province was an institutional audit solution of $38 \%$, then a citizen patrol solution of $20 \%$ and a report solution of $12 \%$, which ranked third. The result of obtaining the rater agreement value of all respondents was $36 \%$. It denotes that the respondents' agreement level was moderate on the order of priority solutions, in the form of institutional audits, citizen patrols, and reports, amounting to $36 \%$.

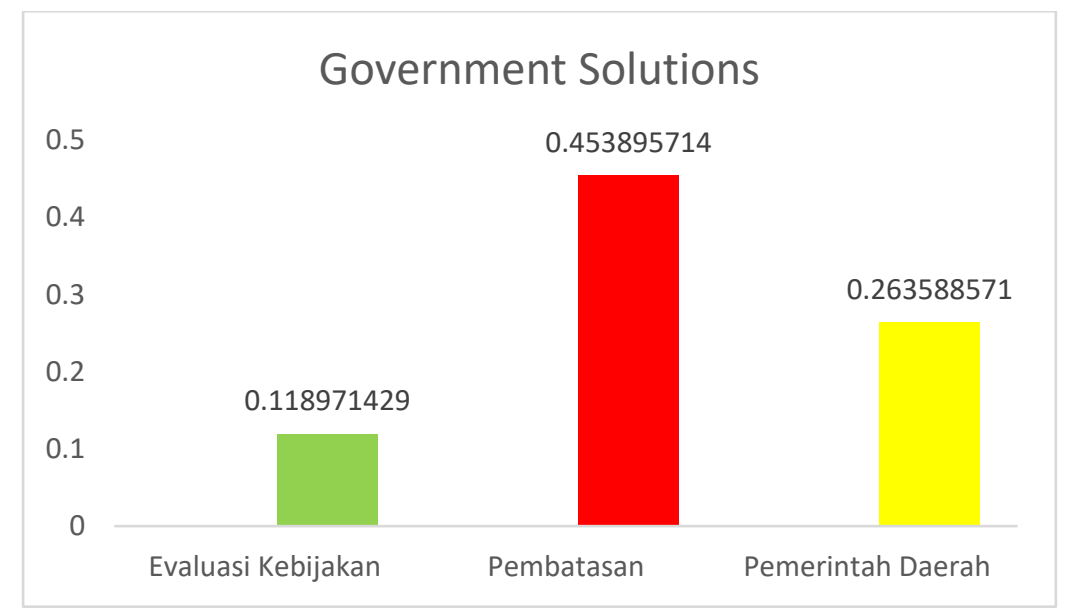

Policy evaluation, restrictions, and local government 


\section{Figure 1.8 Priority Synthesis Results of Government Solution Based on Mean Score}

From Figure 1.8 above, it is shown that based on the combined opinion of the respondents, the most priority solution in determining the forest waqf strategy in protecting indigenous forests in Aceh Province was the solution of restriction by $45 \%$; local government solutions occupied the second priority by $26 \%$; which ranked third was the solution to the visit to the bank by $16 \%$; the last one was the policy evaluation solution of $11 \%$. The result of obtaining the rater agreement value of all respondents was $52 \%$, meaning that the respondents' agreement level was moderate on the order of priority solutions, in the form of restriction solutions, policy evaluations, and local governments with a rater agreement of $52 \%$.

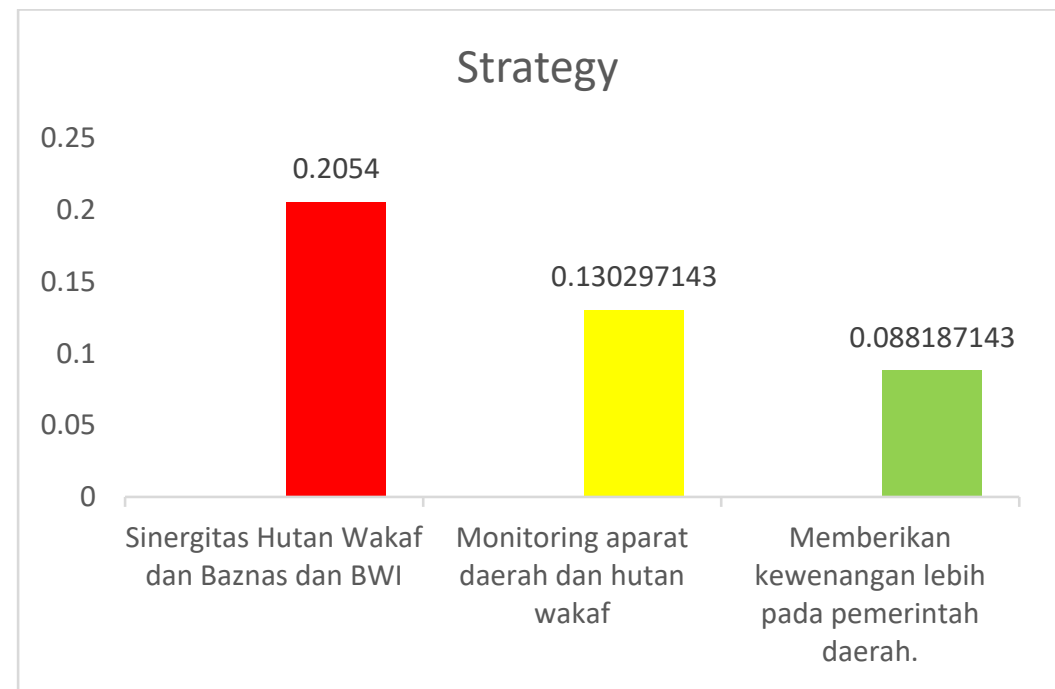

Synergies between forest waqf and BAZNAS and BWI, monitoring local officials and granting authority to local governments

Figure 1.9 Priority Synthesis Results of Strategy Based on Mean Score

Based on the combined opinion of the respondents in Figure 1.9 above, the most priority strategy in determining the forest waqf strategy in protecting indigenous forests in Aceh Province was the synergy of forest waqf and BAZNAS by $20 \%$, followed by monitoring of local officials by $13 \%$ and the granting of authority to local government by $8 \%$. The result of obtaining the rater agreement value of all respondents was $44 \%$. It means that the respondents' agreement level on the sequence of forest waqf strategies in protecting indigenous forests in Aceh Province was in the form of synergies between forest waqf and BAZNAS, monitoring local officials, and granting authority (Mukhtar,2019). 


\section{CONCLUSION}

It can be concluded that the Juntho forest waqf has a tremendous impact on the environment, where critical land has been purchased from 1 hectare to 5 hectares. Meanwhile, the trees planted are ficus/fig-trees, durian, jackfruit, and sentang. In this study, the problem aspects included aspects of the waqf forest itself, the company, and the government, with a rater agreement of $34 \%$. Forest waqf issues comprised operational funds, limited land issues, empowerment, part-time nadhir, with a rater agreement value of $14 \%$ from all respondents. Furthermore, the company's problems, including illegal logging, responsibility, and CSR, were not a priority with a value of $20 \%$. Meanwhile, the government's priority issues were in the form of partiality, profit-oriented, and environmental impacts as the rater agreement value reached $11 \%$. For this reason, the solution for forest waqf covers solutions of infaq and shadaqah funds, waqf institutions, and full-time nadhir by $10 \%$. Solutions for companies are in the form of audit institutions, citizen patrols, and reporting by $36 \%$. The government's solutions are in the form of a restriction solution, policy evaluation, and local government involvement, with a rater agreement value of $52 \%$. Therefore, the strategy of forest waqf in protecting indigenous forests in Aceh Province can be in the form of synergies between forest waqf and BAZNAS, monitoring local officials, and granting authority to local governments, with a rater agreement value of $44 \%$ from all respondents.

\section{REFERENCES}

Ali, K. M., Kassim, S., Jannah, M., \& Ali, Z. M. (2021). Enhancing The Role of Zakat and Waqf on Social Forestry Program in Indonesia. Economica: Jurnal Ekonomi Islam, 12(1), 1-26.

Baird, A. H., \& Kerr, A. M. (2008). Landscape analysis and tsunami damage in Aceh: comment on Iverson and Prasad (2007). Landscape Ecology, 23(1), 35 .

Cochard, R. (2017). Scaling the costs of natural ecosystem degradation and biodiversity losses in Aceh Province, Sumatra. Redefining Diversity \& Dynamics of Natural Resources Management in Asia, Volume 1, 231-271.

Islam, M. S. (2012). Old philosophy, new movement: The rise of the Islamic ecological paradigm in the discourse of environmentalism. Nature and Culture, 7(1), 72-94.

Islam, M. Z. (2013). Legal enforceability of ADR agreement. International Journal of Business and Management Invention, 2(1), 40-43.

Islam, M. Z., Anzum, R., Norullah, M., \& Jahan, A. (2020). CORONAVIRUS DISEASE (COVID-19) AND UNEXPECTED WORLD HEALTH CRISIS. Journal of Asian and African Social Science and Humanities, 6(2), 43-49.

Karam, S. S. (2019). The effect of protected areas on rural communities: Jabal Moussa biosphere reserve case study (Doctoral dissertation).

Mangunjaya, F. M., \& Praharawati, G. (2019). Fatwas on boosting environmental conservation in Indonesia. Religions, 10(10), 570.

Mukhtar, E. (2019). The diversity of wild edible fruit plants and traditional knowledge in West Aceh region, Indonesia. Journal of Medicinal Plants, 7(4), 285-290. 
ROHAINI, R. (2020). The Existence of Tapis As a Traditional Cultural Expression of Lampung Indigenous People.

Suwardi, A. B., NAVIA, Z. I., HARMAWAN, T., \& MUKHTAR, E. (2020). Ethnobotany and conservation of indigenous edible fruit plants in South Aceh, Indonesia. Biodiversitas Journal of Biological Diversity, 21(5).

Yaakob, A., Mahzir, N., Supaat, D. I., Zakaria, M. Z., Wook, I., \& Mustafa, M. (2017). Waqf as a means of forest conservation: Alternative for Malaysia. Advanced Science Letters, 23(5), 4860-4864.

Yeoh, S. C. (1994). Umara-ulama-ummah relations and pesantrens in Aceh Province, Indonesia: A study of the challenges to the authority of a traditional kiyai (Doctoral dissertation, University of Washington).

Zulfan, Z. (2018). Model of Local Wisdom Legal Source and State Law in Aceh Government. Indonesian Comparative Law Review, 1(1), 51-68. 